\title{
Lipopeptide-Induced Suicidal Erythrocyte Death Correlates with the Degree of Acylation
}

\author{
Abdulla Al Mamun Bhuyan ${ }^{\mathrm{a}} \quad$ Minh-Thu Nguyen ${ }^{\mathrm{b}}$ Rosi Bissinger ${ }^{\mathrm{a}}$ Florian Langa,c \\ Friedrich Götz ${ }^{\mathrm{b}}$ \\ Departments of a Cardiology, Vascular Medicine and Physiology and ${ }^{\mathrm{b} M i c r o b i a l}$ Genetics, Eberhard- \\ Karls-University of Tuebingen, Tuebingen, 'Department of Molecular Medicine II, Heinrich Heine \\ University Duesseldorf, Germany
}

\section{Key Words}

Lipopeptide $・$ Phosphatidylserine $・$ Eryptosis $・$ Apoptosis $・$ Pam

\begin{abstract}
Background/Aims: Consequences of bacterial infection include anemia, which could result from stimulation of suicidal erythrocyte death or eryptosis, characterized by cell shrinkage and cell membrane scrambling with phosphatidylserine translocation to the erythrocyte surface. Bacterial components known to stimulate eryptosis include lipopeptides. Signaling mediating the triggering of eryptosis include increased cytosolic $\mathrm{Ca}^{2+}$ activity $\left(\left[\mathrm{Ca}^{2+}\right]_{\mathrm{i}}\right)$, oxidative stress and cellular accumulation of ceramide. The present study aimed to define the molecular requirements for lipopeptide-induced cell membrane scrambling. Methods: Human erythrocytes were incubated for 48 hours in the absence and presence of 1 or $5 \mu \mathrm{g} / \mathrm{ml}$ of the synthetic lipopeptides Pam1 (lipopeptide with one fatty acid), Pam2 (lipopeptide with two fatty acids), or Pam3 (lipopeptide with three fatty acids). In the following phosphatidylserine exposure at the cell surface was estimated from annexin-V-binding, cell volume from forward scatter, $\left[\mathrm{Ca}^{2+}\right]_{i}$ from Fluo3-fluorescence, ROS formation from DCF dependent fluorescence, and ceramide abundance utilizing specific antibodies. Results: Pam1 $(5 \mu \mathrm{g} / \mathrm{ml})$, Pam2 $(5 \mu \mathrm{g} / \mathrm{ml})$ and Pam3 ( 1 and $5 \mu \mathrm{g} / \mathrm{ml}$ ) significantly increased the percentage of annexin-V-binding to erythrocytes in a dose dependent manner, which was largely independent of $\mathrm{Ca}^{2+}$. Pam1-3 increased the percentage of both, swollen and shrunken erythrocytes without significantly modifying the average forward scatter. They also increased reactive oxygen species (ROS) and ceramide abundance. In all assays the effect on eryptosis increased with increasing number of fatty acids, with Pam3 showing always the strongest effect. In contrast, a comparison of the effect of Pam1-3 on TLR2 dependent immune stimulation showed that not Pam3 but Pam2 displayed the strongest activity, and that immune stimulation was triggered at much lower concentrations than eryptosis. Conclusions: Lipopeptides are not only important activators of the immune system; at higher concentrations they also drive host cells into apoptosis thus aggravating a bacterial infection.

A. Al Mamun Bhuyan and M.T. Nguyen contributed equally and thus share first authorship

Friedrich Götz

and Florian Lang

KARGER
Microbial Genetics, Interfaculty Institute of Microbiology and Infection Medicine (IMIT), University of Tuebingen, Auf der Morgenstelle 28, 72076 Tuebingen, and Department of Internal Medicine III, University of Tuebingen, Gmelinstr. 5, 72076 Tuebingen (Germany) E-Mail friedrich.goetz@uni-tuebingen.de / florian.lang@uni-tuebingen.de 


\section{Introduction}

The lipopeptides (Lpp) used in this study are structural components found in almost all bacterial membranes. They represent the membrane anchor group of the lipoproteins that play a crucial role in transport processes as reviewed recently [1, 2]. As they are so characteristic for bacteria it does not astonish that the mammalian immune system responds to the Lpp moiety of bacterial lipoproteins by inducing an innate immune response via the TLR2 receptor [3]. Lpp are not only potent stimulators of the innate immune system [1, 4], they also have strong adjuvant activity $[5,6]$. Their TLR2 activation leads via a cascade of intermediary steps to NF-kappaB activation [7]. Dependent on the degree of acylation, Lpp are recognized by different TLR2 heterodimers. Diacylated Lpp are recognized by TLR2 and TLR6 $[8,9]$, while triacylated Lpp are recognized by TLR2 and TLR1 heterodimers $[3,10]$. The signal transduction from Lpp-bound TLR2 to the activation of the nuclear factor NFkappaB involves a cascade of phosphorylation events [11]. Besides triggering the innate immune response they also induce apoptosis in THP-1 monocytic cells through TLR2 and also initiate apoptosis in an epithelial cell line transfected with hTLR2 [4].

Because of this activity it would be interesting to investigate the effect of Lpp on other host cells such as the enucleated mammalian erythrocytes. They represent the most abundant cells in the bloodstream and transport oxygen to and $\mathrm{CO}_{2}$ from peripheral tissues. Any injury of erythrocytes affecting their quantity, shape, size, structure or life cycle can affect the oxygen-carrying capacity of the blood. Bacterial sepsis for example may cause anemia, which partially results from eryptosis, the suicidal death of erythrocytes characterized by cell membrane scrambling with phosphatidylserine (PS) exposure at the erythrocyte surface [12]. Signaling of eryptosis includes increase of cytosolic $\mathrm{Ca}^{2+}$ activity $\left(\left[\mathrm{Ca}^{2+}\right]_{\mathrm{i}}\right)[13]$, ceramide [14], oxidative stress [13], energy depletion [13], heterotrimeric G-protein subunit Gai2 [15], caspases [13, 16, 17], casein kinase $1 \alpha[13]$, Janus-activated kinase JAK3 [13], protein kinase C [13], and p38 kinase [13]. Eryptosis is inhibited by AMP activated kinase AMPK [13], cGMP-dependent protein kinase [13], PAK2 kinase [13], mitogen- and stress-activated kinase MSK1/2 [18], as well as sorafenib/sunitinib sensitive kinases [13]. Enhanced eryptosis contributes to anemia in a variety of clinical conditions [15, 19-27] and is enhanced following blood storage for transfusion [28]. Eryptosis is triggered by many xenobiotics [13, 16, 20, 21, 25, 29-71] including bacterial Lpp [72]. However, the structural requirements for bacterial Lpp-induced eryptosis are ill-defined.

The present study explored, whether differentially acylated Lpp, Pam1-3, stimulates eryptosis and to which extent. We tested human erythrocytes from healthy volunteers and exposed them to Pam1-3 and determined PS surface abundance, cell volume, $\left[\mathrm{Ca}^{2+}\right]_{\mathrm{i}}$, ROS formation, and ceramide abundance. Interestingly, the extent of eryptosis increased with increasing number of fatty acids bound to the lipid moiety of the Lpp, while for immune stimulation Pam2, the diacylated Lpp, showed the strongest effect and was triggered at much lower concentrations than eryptosis.

\section{Materials and Methods}

Erythrocytes, solutions and chemicals

Fresh Li-Heparin-anticoagulated blood samples were kindly provided by the blood bank of the University of Tübingen. The study is approved by the ethics committee of the University of Tübingen (184/2003 V). The blood was centrifuged at $120 \mathrm{~g}$ for $20 \mathrm{~min}$ at $21^{\circ} \mathrm{C}$ and the platelets and leukocytes-containing supernatant was disposed. Erythrocytes were incubated in vitro at a hematocrit of $0.4 \%$ in Ringer solution containing (in $\mathrm{mM}$ ) $125 \mathrm{NaCl}, 5 \mathrm{KCl}, 1 \mathrm{MgSO}_{4}, 32 \mathrm{~N}$-2-hydroxyethylpiperazine-N-2-ethanesulfonic acid (HEPES; pH 7.4), 5 glucose, 1 $\mathrm{CaCl}_{2}$, at $37^{\circ} \mathrm{C}$ for 48 hours. Where indicated, erythrocytes were exposed for 48 hours to the synthetic Lpp Pam 1 , Pam2 and Pam3 (for their structure see Fig . 1). In order to estimate the impact of $\mathrm{Ca}^{2+}$ entry, erythrocytes were exposed in the presence and nominal absence $\left(0 \mathrm{CaCl}_{2}, 1 \mathrm{mM} \mathrm{EGTA}\right)$ of $\mathrm{Ca}^{2+}$. 


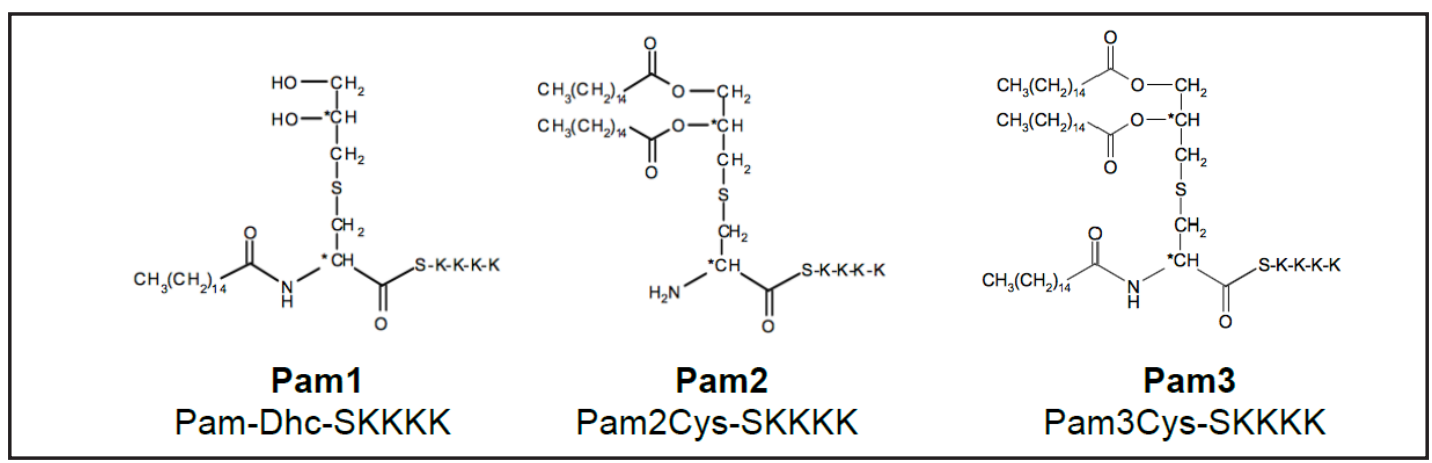

Fig. 1. Chemical structure of Pam1, Pam2 and Pam3.

\section{Annexin-V-binding and forward scatter}

After incubation under the respective experimental condition, a $150 \mu \mathrm{l}$ cell suspension was washed in Ringer solution containing $5 \mathrm{mM} \mathrm{CaCl}_{2}$ and then stained with Annexin-V-FITC (1:200 dilution; ImmunoTools, Friesoythe, Germany) in this solution at $37^{\circ} \mathrm{C}$ for $15 \mathrm{~min}$ under protection from light. The annexin-Vabundance at the erythrocyte surface was subsequently determined on a FACS Calibur (BD, Heidelberg, Germany). Annexin-V-binding was measured with an excitation wavelength of $488 \mathrm{~nm}$ and an emission wavelength of $530 \mathrm{~nm}$. A marker (M1) was placed to set an arbitrary threshold between annexin-V-binding cells and control cells. The same threshold was used for untreated and Pam1-3 treated erythrocytes. Light scattering is an empirical technique employed to measure rapid changes in cell volume [73]. Here we used a dot plot of forward scatter (FSC) vs. side scatter (SSC) that was set to linear scale for both parameters. The threshold of forward scatter was set at the default value of " 52 ".

\section{Intracellular $\mathrm{Ca}^{2+}$}

After incubation, erythrocytes were washed in Ringer solution and loaded with Fluo-3/AM (Biotium, Hayward, USA) in Ringer solution containing $5 \mathrm{mM} \mathrm{CaCl}_{2}$ and $5 \mu \mathrm{M}$ Fluo-3/AM. The cells were incubated at $37^{\circ} \mathrm{C}$ for $30 \mathrm{~min}$. $\mathrm{Ca}^{2+}$-dependent fluorescence intensity was measured with an excitation wavelength of 488 $\mathrm{nm}$ and an emission wavelength of $530 \mathrm{~nm}$ on a FACS Calibur.

\section{Reactive oxygen species (ROS)}

Oxidative stress was determined utilizing 2',7'-dichlorodihydrofluorescein (DCF) diacetate. After incubation, a $150 \mu \mathrm{l}$ suspension of erythrocytes was washed in Ringer solution and stained with DCF (Sigma, Schnelldorf, Germany) in Ringer solution containing DCF at a final concentration of $10 \mu \mathrm{M}$. Erythrocytes were incubated at $37^{\circ} \mathrm{C}$ for $30 \mathrm{~min}$ in the dark and washed two times in Ringer solution. The DCF-loaded erythrocytes were resuspended in $200 \mu \mathrm{l}$ Ringer solution and ROS-dependent fluorescence intensity was measured at an excitation wavelength of $488 \mathrm{~nm}$ and an emission wavelength of $530 \mathrm{~nm}$ on a FACS Calibur (BD).

\section{Ceramide abundance}

For the determination of ceramide abundance at the erythrocyte surface, a monoclonal antibody-based assay was used. To this end, cells were stained for 1 hour at $37^{\circ} \mathrm{C}$ with $1 \mu \mathrm{g} / \mathrm{ml}$ anti ceramide antibody (clone MID 15B4, Alexis, Grünberg, Germany) in PBS containing 0.1\% bovine serum albumin (BSA) at a dilution of 1:10. The samples were washed twice with PBS-BSA. The cells were stained for 30 minutes with polyclonal fluorescein isothiocyanate (FITC) conjugated goat anti-mouse IgG and IgM specific antibody (Pharmingen, Hamburg, Germany) diluted 1:50 in PBS-BSA. Unbound secondary antibody was removed by repeated washing with PBS-BSA. The samples were analyzed by flow cytometric analysis with an excitation wavelength of $488 \mathrm{~nm}$ and an emission wavelength of $530 \mathrm{~nm}$. As a control, secondary antibody alone was used.

\section{HEK-TLR2 signaling assay}

Human Embryonic Kidney (HEK 293) cells, stably transfected with the human TLR2 gene, were purchased from Invivogen. The cultivation was performed following the previous study [74]. For the signaling stimulation assay, HEK-TLR2 cells were seeded $5 \times 10^{4}$ cells/ $200 \mu$ l well into 96 well cell culture 
plates and incubated at $37^{\circ} \mathrm{C}$ with $5 \% \mathrm{CO}_{2}$. After one-day incubation, the HEK-TLR2 cells were used for the stimulation test. $100 \mathrm{ng}$ of different synthetic Lpp including Pam1C, Pam2C and Pam3C were dissolved in $10 \mu \mathrm{l}$ of $\mathrm{H}_{2} \mathrm{O}$ and transferred to the $200 \mu \mathrm{l}$ medium containing approximately $1 \mathrm{x} 10^{5}$ HEK-TLR2 cells. The negative controls (unsti.) were used with $10 \mu \mathrm{l}$ of $\mathrm{H}_{2} \mathrm{O}$. Stimulation was carried out for $18 \mathrm{~h}$ at $37^{\circ} \mathrm{C}$ with $5 \%$ $\mathrm{CO}_{2}$. The supernatants were collected and stored at $-20^{\circ} \mathrm{C}$. Human IL-8 secretion was measured in cellular supernatants using the BD OptEIA ELISA kits according to the manufacturer's instructions.

\section{Statistics}

Data are expressed as arithmetic means \pm SEM. As indicated in the figure legends, statistical analysis was made using ANOVA with Tukey's test as post-test and $t$ test as appropriate. $\mathrm{N}$ denotes the number of different erythrocyte specimens studied. Since different erythrocyte specimens used in distinct experiments are differently susceptible to triggers of eryptosis, the same erythrocyte specimens have been used for control and experimental conditions.

\section{Results}

In the present study we investigated the stimulating effect of the differently acylated Lpp (Pam1, Pam2 and Pam3) on eryptosis, which is the suicidal erythrocyte death characterized by cell shrinkage and phospholipid scrambling of the cell membrane triggered by PS translocation to the cell surface. In the following we analyzed various parameters known to be typical for eryptosis.

\section{Lpp induced translocation of PS to the cell surface}

Surface exposed PS was identified by annexin-V-binding and subsequent flow cytometry. Prior to measurements, the erythrocytes were again incubated for 48 hours in Ringer solution without or with Pam1-3 (1 - $5 \mu \mathrm{g} / \mathrm{ml})$. All three Lpp triggered annexin binding, which was consecutively increased with increasing acylation of the Lpp (Fig. 2). Pam3 even revealed a sixfold higher annexin binding than Pam 1 and the binding with Pam 2 was in between. The increase in annexin binding was also concentration dependent; $5 \mu \mathrm{g} / \mathrm{ml}$ triggered an almost fivefold stronger binding than $1 \mu \mathrm{g} / \mathrm{ml}$.

\section{Lpp modulated cell volume}

Erythrocyte volume was estimated by forward scatter and flow cytometry. Prior to measurements, the erythrocytes were incubated for 48 hours in Ringer solution without or

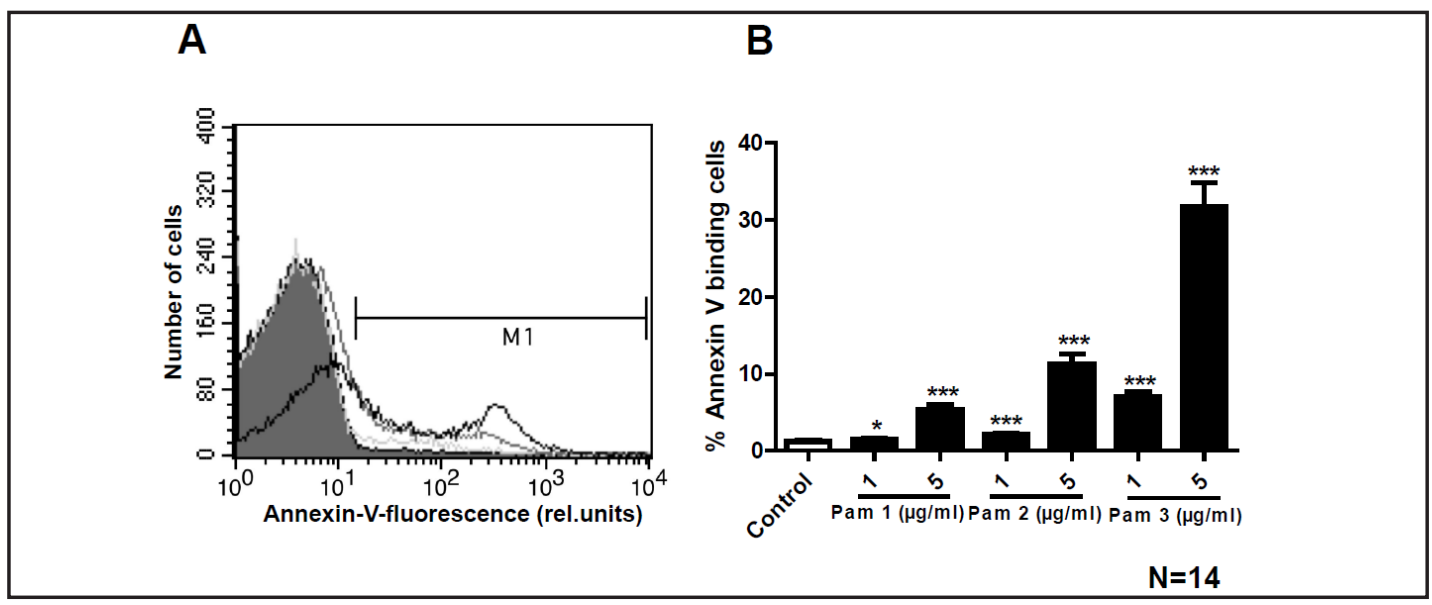

Fig. 2. Effect of Pam1-3 on phosphatidylserine exposure. (A) Original histograms of annexin-V-binding of erythrocytes following exposure for 48 hours to Ringer solution without (grey areas, control) and in the presence of $5 \mu \mathrm{g} / \mathrm{ml}$ Pam1 (light grey line), Pam2 (deep grey line), or Pam3 (black line). (B) Arithmetic means \pm SEM $(n=14)$ of erythrocyte annexin-V-binding following incubation for 48 hours to Ringer solution without (white bar) or with 1 and $5 \mu \mathrm{g} / \mathrm{ml}$ Pam1-3 (black bars). ${ }^{*}(\mathrm{p}<0.05),{ }^{* * *}(\mathrm{p}<0.001)$ indicate significant difference from the absence of Pam's.

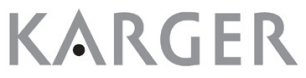


with Pam1-3 (1 and $5 \mu \mathrm{g} / \mathrm{ml}$ ). Pam1-3 in a concentration of $1 \mu \mathrm{g} / \mathrm{ml}$ did not appreciably alter cell volume (Fig. 3). However, at a concentration of $5 \mu \mathrm{g} / \mathrm{ml}$ there was a clear cell shrinkage observed with Pam1, with Pam2 the control volume was reached, and with Pam3 a clear increase beyond the control volume was observed (Fig. 3). We assume that the observed cell shrinkage with $5 \mu \mathrm{g} / \mathrm{ml}$ of Pam 1 was due to an increase of cytosolic $\mathrm{Ca}^{++}$concentration which further activates the Gardos channel, resulting in hyperpolarization of the cell membrane resulting in loss of $\mathrm{K}^{+}$, $\mathrm{Cl}$ - ions and $\mathrm{H}_{2} \mathrm{O}$ from the cell [75]. Pam3 increased cell volume [76].

\section{Lpp increased intracellular $\mathrm{Ca}^{2+}$ concentration.}

Cytosolic $\mathrm{Ca}^{2+}$ activity $\left(\left[\mathrm{Ca}^{2+}\right]_{\mathrm{i}}\right)$ was determined by Fluo3 fluorescence. As shown in Fig. 4, a 48 hours exposure to Pam1-3 increased the Fluo3 fluorescence, an effect reaching statistical significance at $5 \mu \mathrm{g} / \mathrm{ml} \mathrm{Pam} 2$ and at 1 and $5 \mu \mathrm{g} / \mathrm{ml} \mathrm{Pam} 3$; Pam 1 showed no effect.

Lpp induced translocation of PS to the cell surface in the absence of $\mathrm{Ca}^{2+}$

A next series of experiments explored whether the Pam1-3-induced translocation of PS required the entry of extracellular $\mathrm{Ca}^{2+}$. Therefore, erythrocytes were incubated for 48

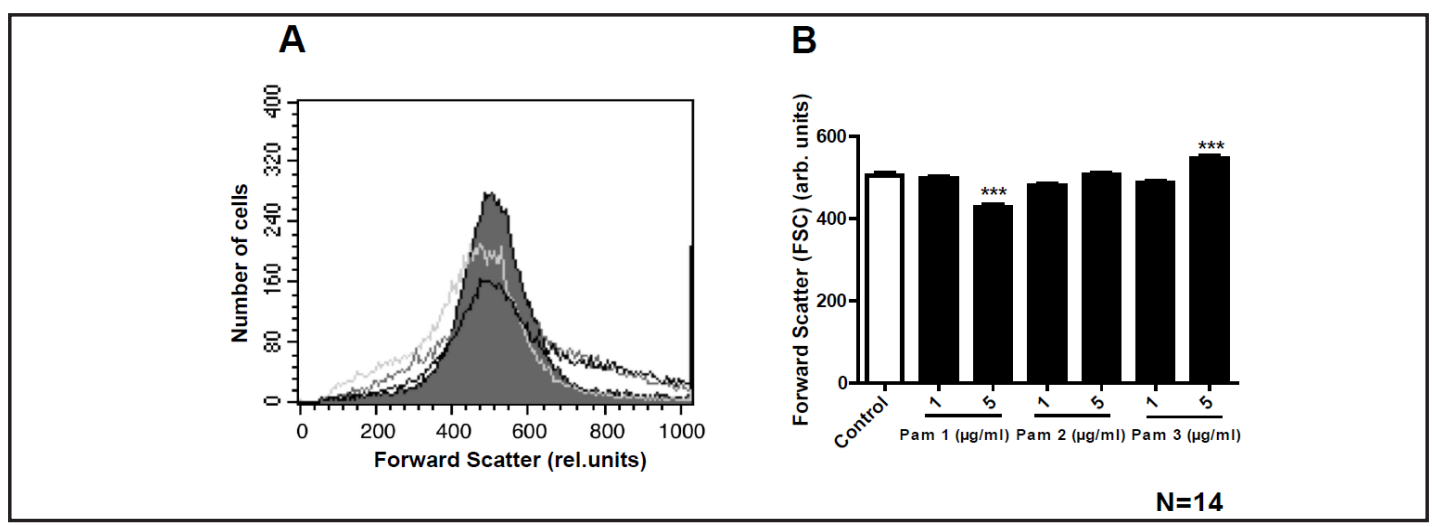

Fig. 3. Effect of Pam1-3 on erythrocyte forward scatter. (A) Original histograms of forward scatter of erythrocytes following exposure for 48 hours to Ringer solution without (grey areas, control) and in the presence of $5 \mu \mathrm{g} / \mathrm{ml}$ Pam1 (light grey line), Pam2 (deep grey line), or Pam3 (black line). (B) Arithmetic means \pm SEM ( $\mathrm{n}=14$ ) of the erythrocyte forward scatter (FSC) following incubation for 48 hours to Ringer solution without (white bar) or with 1 or $5 \mu \mathrm{g} / \mathrm{ml}$ Pam1-3 (black bars). ${ }^{*}(\mathrm{p}<0.05),{ }^{* * *}(\mathrm{p}<0.001)$ indicate significant difference from the absence of Pam's.

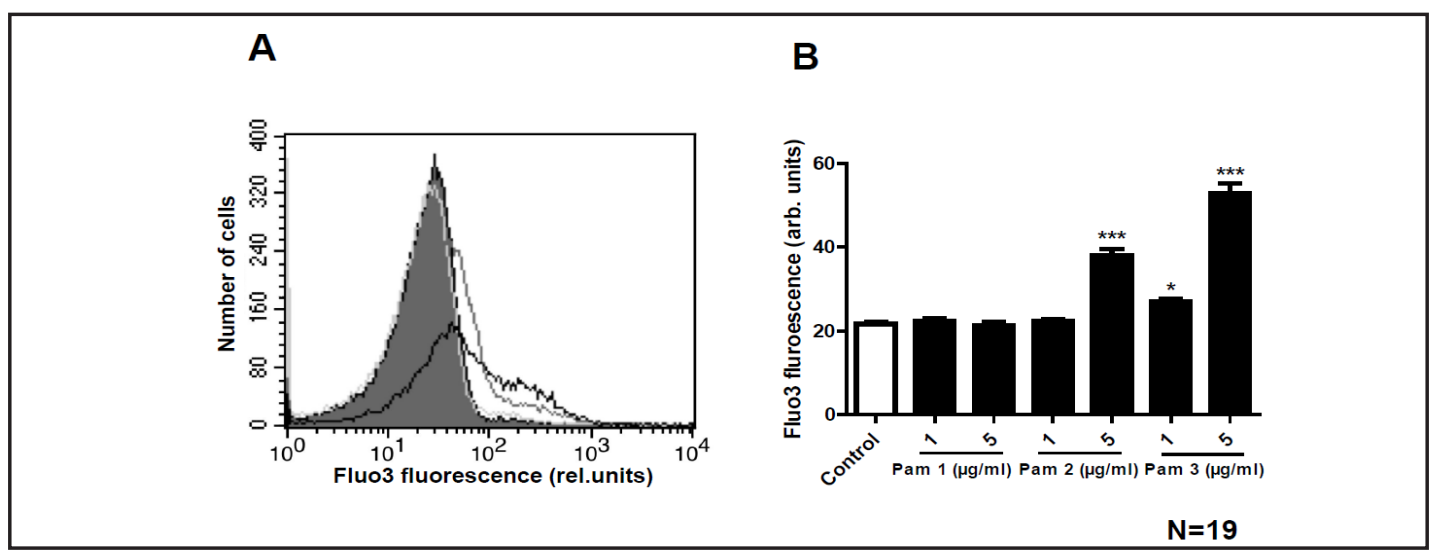

Fig. 4. Effect of Pam1-3 on Fluo3 fluorescence. (A) Original histograms of Fluo3 fluorescence in erythrocytes following exposure for 48 hours to Ringer solution without (grey areas) and in the presence of 5 $\mu \mathrm{g} / \mathrm{ml}$ Pam1, Pam2, or Pam3 (black lines). (B). Arithmetic means \pm SEM ( $\mathrm{n}=19)$ of Fluo3 fluorescence in erythrocytes following incubation for 48 hours to Ringer solution without (white bar) or with 1 and $5 \mu \mathrm{g} /$ ml Pam1-3 (black bars). * $(\mathrm{p}<0.05),{ }^{* * *}(\mathrm{p}<0.001)$ indicate significant difference from the absence of Pam's.

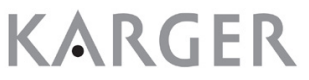


hours in the absence or presence of $5 \mu \mathrm{g} / \mathrm{ml} \mathrm{Pam} 1-3$ in the presence or nominal absence of extracellular $\mathrm{Ca}^{2+}$. As illustrated in Fig. 5, removal of extracellular $\mathrm{Ca}^{2+}$ significantly blunted the effect of Pam1, of Pam2 and of Pam3 on annexin-V-binding. However, even in the absence of extracellular $\mathrm{Ca}^{2+}$, Pam1, Pam2 and Pam3 significantly increased annexin-V-binding of erythrocytes. Thus, the annexin-V-binding following exposure to Pam1, Pam2 and Pam3 was in part but not fully dependent on entry of extracellular $\mathrm{Ca}^{2+}$ (Fig. 5). The presence of $\mathrm{Ca}^{2+}$ led to an increase in annexin $\mathrm{V}$ binding following administration of all three Lpp. Compared to Pam1, Pam2 caused roughly 2-times higher and Pam3 even 6-times higher annexin V binding. A similar correlation, but less pronounced was observed in the absence of $\mathrm{Ca}^{2+}$, which was strange as it is known that $\mathrm{Ca}^{++}$is one of the most important activators of the TMEM16F scramblase [77].

\section{Lpp induced oxidative stress}

Indeed, eryptosis is further stimulated by oxidative stress. Reactive oxygen species (ROS) were quantified utilizing $2^{\prime}, 7^{\prime}$-dichlorodihydrofluorescein (DCF) diacetate. DCF itself is a fluorogenic substance and when it crosses the cell membrane, the intracellular esterases deacetylate DCF to an impermeable, non fluoresecent product. But later the reactive oxygen species convert this DCF into $2^{\prime} 7^{\prime}$-dichlorofluorescein (DCF) by oxidation which is a highly florescent compound that can be detected easily by flow cytometry. As shown in Fig. 6, a 48 hours exposure to $5 \mu \mathrm{g} / \mathrm{ml} \mathrm{Pam} 2$ and Pam3, but not Pam1, increased significantly the DCF dependent fluorescence, with Pam3 exerting the strongest effect.

Fig. 5. $\mathrm{Ca}^{2+}$ sensitivity of Pam1-3 induced phosphatidylserine exposure. (A-C) Original histogram of annexin-V-binding of erythrocytes following exposure for 48 hours to Ringer solution in the presence (left panels) and absence (right panels) of extracellular $\mathrm{Ca}^{2+}$. Black line indicates the presence of each $5 \mu \mathrm{g} / \mathrm{ml}$ of Pam1 (A), Pam2 (B) or Pam3 (C). (D) Arithmetic means \pm SEM ( $n=4$ ) of annexin-V-binding of erythrocytes after a 48 hours treatment with Ringer solution without (white bars) or with 5 $\mu \mathrm{g} / \mathrm{ml}$ Pam1-3 (black bars) in the presence (left bars, $+\mathrm{Ca}^{2+}$ ) and absence (right bars, $-\mathrm{Ca}^{2+}$ ) of $\mathrm{Ca}^{2+}$. ${ }^{* *}(\mathrm{p}<0.01),{ }^{* * *}(\mathrm{p}<0.001)$ indicates significant difference from the absence of PAM1, \#\#\# $(\mathrm{p}<0.001)$ indicate significant difference from presence of $\mathrm{Ca}^{2+}$ (ANOVA).

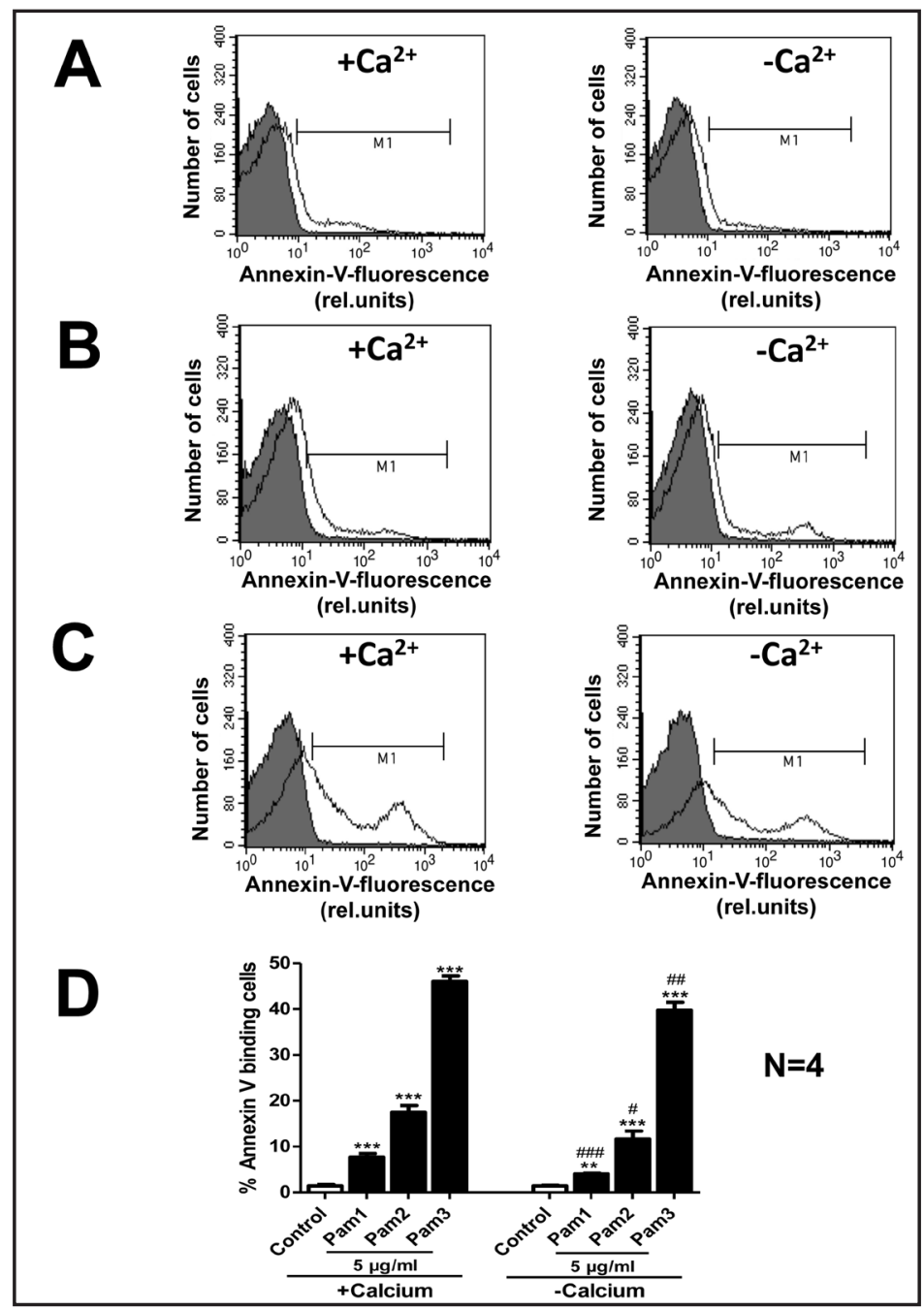




\section{Lpp increased ceramide abundance}

A further stimulator of eryptosis is ceramide. Ceramide abundance at the erythrocyte surface was thus quantified utilizing specific antibodies. As shown in Fig. 7, a 48 hours exposure to $5 \mu \mathrm{g} / \mathrm{ml} \mathrm{Pam} 2$ and Pam3, but not Pam1, significantly increased the ceramide abundance. The effect of Pam3 was even 5-times stronger than that of Pam2.

\section{Lpp Pam2 exerted the strongest immune stimulation}

Finally, we investigated the TLR2 dependent signaling of Pam1-3 in Human Embryonic Kidney (HEK 293) cells, stably transfected with the human TLR2 gene. IL-8 production was determined after stimulation of the cells with $0.5 \mu \mathrm{g} / \mathrm{ml}$ of Pam1, Pam2 or Pam3 for $18 \mathrm{~h}$. While Pam1 showed no signaling activity at all, Pam2 showed the highest activity which was even twofold higher than that of Pam3 (Fig. 8).

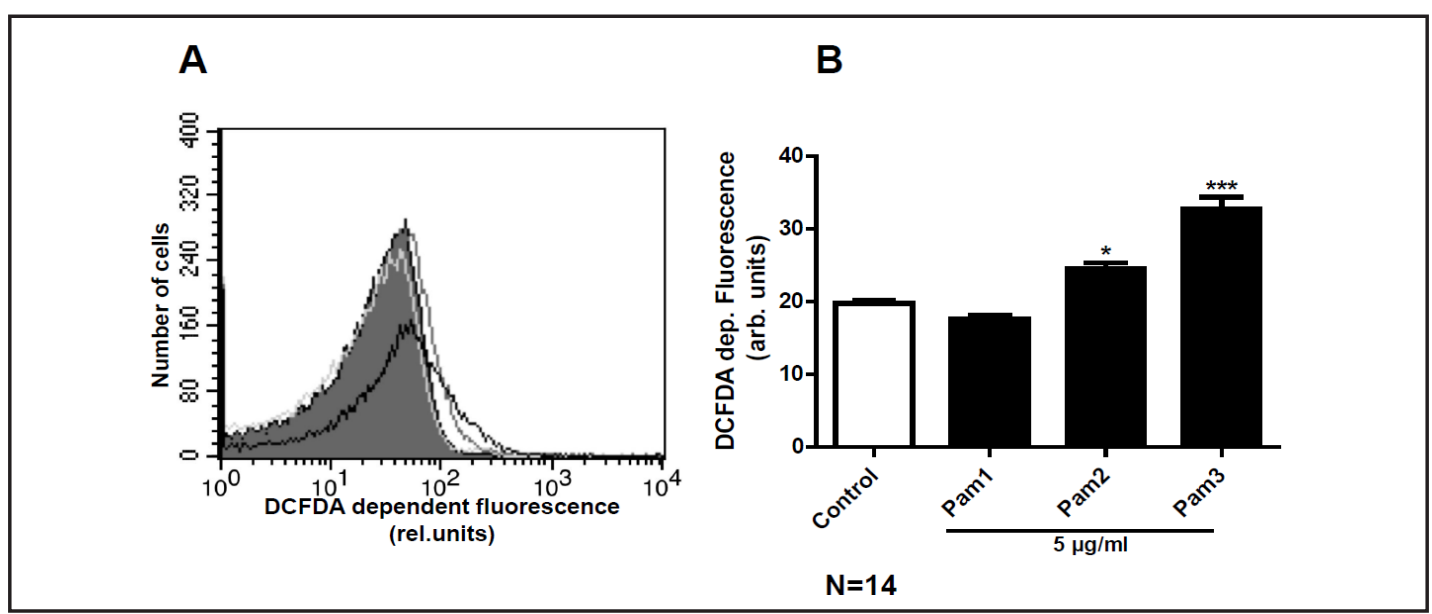

Fig. 6. Effect of Pam1-3 on DCF fluorescence. (A) Original histograms of DCF fluorescence in erythrocytes following exposure for 48 hours to Ringer solution without (grey areas) and in the presence of $5 \mu \mathrm{g} / \mathrm{ml}$ Pam1, Pam2, or Pam3 (black lines). (B) Arithmetic means \pm SEM ( $n=14$ ) of DCF fluorescence in erythrocytes following incubation for 48 hours to Ringer solution without (white bar) or with $5 \mu \mathrm{g} / \mathrm{ml}$ Pam1-3 (black bars). * $(\mathrm{p}<0.05),{ }^{* * *}(\mathrm{p}<0.001)$ indicate significant difference from the absence of Pam's.

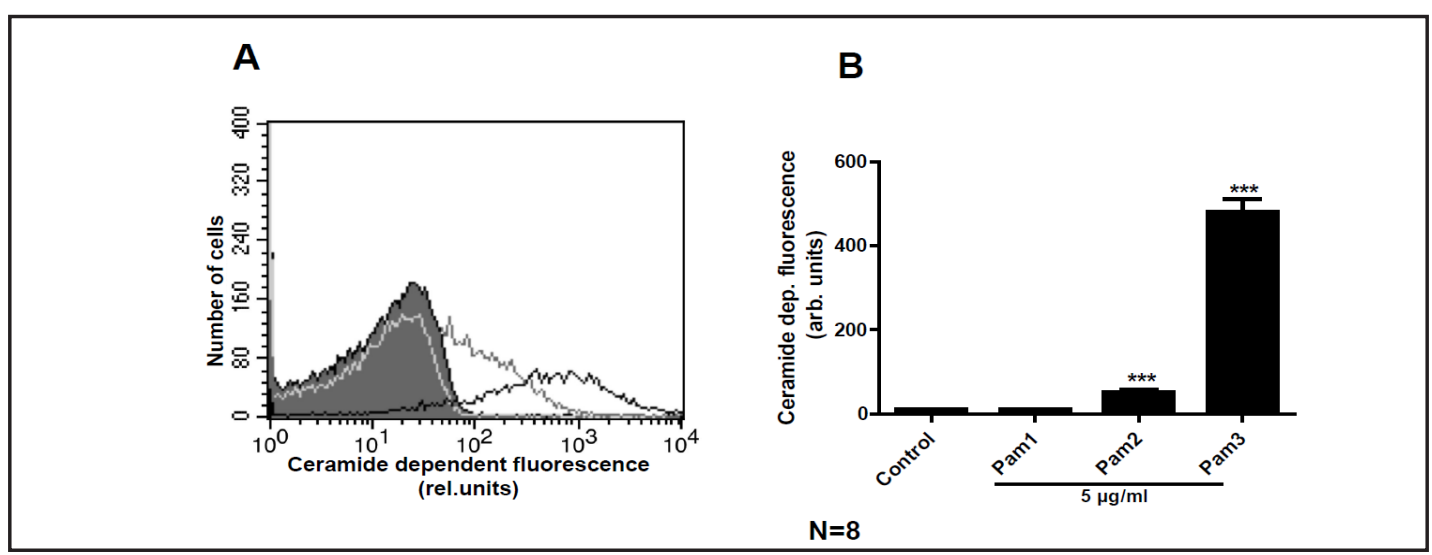

Fig. 7. Effect of Pam1-3 on ceramide abundance. (A) Original histograms of ceramide abundance at the surface of erythrocytes following exposure for 48 hours to Ringer solution without (grey areas) and in the presence of $5 \mu \mathrm{g} / \mathrm{ml}$ Pam1 (light grey line), Pam2 (deep grey line), and Pam3 (black line). (B) Arithmetic means \pm SEM $(n=8)$ of ceramide abundance at the surface of erythrocytes following incubation for 48 hours

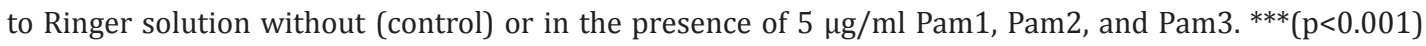
indicate significant difference from the absence of Pam's.

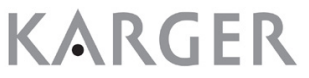


Fig. 8. Induction of IL8 production with HEK-TLR2 cells triggered with Pam1-3. HEK-TLR2 cells were stimulated for $18 \mathrm{~h}$ with each $0.5 \mu \mathrm{g} / \mathrm{ml}$ of either Pam1, Pam2 or Pam3. The human IL8 cytokine was used as readout for immune stimulation and was measured by Elisa kit. The un-stimulated sample (unsti.) was used as negative control by the application of $10 \mu \mathrm{l}$ of $\mathrm{H}_{2} \mathrm{O}$. The experiments were independently carried out three times. Statistical significances were calculated by using Student's t-tests of different samples versus the Pam1: not significant $\mathrm{P}>0.05,{ }^{*} \mathrm{P}<0.05$, ** $\mathrm{P}<0.001$, *** $\mathrm{P}<0.0001$.

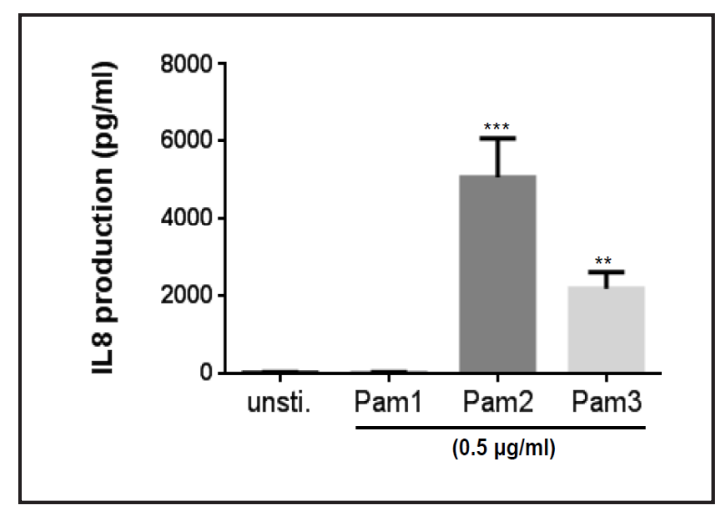

\section{Discussion}

Bacterial lipopeptides (Lpp) represent not only a major class of membrane-anchored surface proteins in Gram-positive bacteria, they also play a crucial role in innate immune stimulation via TLR2 activation [1]. Until recently it was not clear whether low-GC Grampositive bacteria produce di- or triacylated Lpp. However, Kurokawa and colleagues showed that in $S$. aureus the $33 \mathrm{kDa} \mathrm{SitC}$, a component of the proposed iron $\mathrm{ABC}$ transporter SitABC, is triacylated and induces IL- 6 and TNF- $\alpha$ release in human monocytes and NFkB-activation in TLR2-transfected HEK293 cells [78]. However, recently it has been shown that some other bacterial species produce only diacylated Lpp showing a much stronger immune stimulation and inflammation response than triacylated Lpp [79]. The question we raised here was whether diacylated Lpp have also a stronger impact on mammalian cell damage than triacylated ones. To facilitate the task we have chosen synthetic Lpp that were mono-, di- and triacylated, each with palmitate as fatty acid (Fig. 1). As model cells we have chosen human erythrocytes from volunteers. Like in other mammalian cells in the normal erythrocyte membrane PS are located exclusively in the inner leaflet [80]. The loss of membrane asymmetry and the exposure of PS affects the hemostatic balance in a number of ways [81]: PS-presenting erythrocytes adhere to endothelial cell monolayers [82], they are prone to eryptosis with the consequence that they are removed by macrophages like many other senescent or virus- and bacteria-infected cells [83, 84]; surface-exposed PS represents an 'eat-me' signal [85].

Exposure of Pam1, Pam2 and Pam3 to erythrocytes induced all the classical features of eryptosis such as increased exposure of PS on the surface, which was largely $\mathrm{Ca}^{2+}$ independent, an increased cytosolic $\mathrm{Ca}^{2+}$ activity $\left(\left[\mathrm{Ca}^{2+}\right]_{\mathrm{i}}\right)$, increased oxidative stress, and an increased ceramide abundance. The important result of this study was that the degree of all the eryptosis signs correlated with the degree of the acylation of the Lpp; Pam3 always exerted the strongest effect.

The question remains how Pam1-3 mediate eryptosis. Do they activate the Ca-dependent phospholipid scramblase (TMEM16F), or distort the erythrocyte membrane in such a way that the scramblases get activated even in the absence of $\mathrm{Ca}^{2+}$ ? As the annexin $\mathrm{V}$ binding increased with increasing degree of acylation of the Lpp we assume that the lipophilicity plays a crucial role in scramblase activation even in the absence of $\mathrm{Ca}^{2+}$. As in Pam3 the lipophilicity of the Lpp is highest we speculated that Pam3 might act like a detergent that disintegrates the erythrocyte membrane.

We also wondered why there was a relatively high annexin binding in the absence of $\mathrm{Ca}^{2+}$. An explanation could be that Pam1-3-induced lipid peroxidation was due to oxidative stress [86]. Reduced glutathione may be oxidized and thus be unable to protect the cell from oxidative stress [87]. Indeed, we found that Lpp induced oxidative stress and ceramide production, which might explain why they are able to activate the scramblase in the absence of $\mathrm{Ca}^{2+}$. 
The observation that increasing degree of Lpp-acylation correlated with increasing eryptosis indicates that increasing lipophilicity causes more damage to the plasma membrane. Cyclic lipopeptides constitute a structurally diverse group of metabolites produced by various bacterial and fungal genera via non-ribosomal pathways [88]. Structurally they are amphiphilic molecules that comprise both hydrophobic and hydrophilic moieties; in this respect they resemble our Lpp. However, they are built up as cyclic peptide that carries one alkyl chain. Most of them attack cell membranes and are used as antimicrobials, antitumor drugs or surfactants. One of the most aggressive cyclic lipopeptides is surfactin. It has a high detergent effect by inserting its fatty acid chain into the lipid bilayer $[89,90]$. Its cell destruction is indiscriminate, and it attacks also erythrocytes with deadly efficiency. Pseudofactins inhibit bacterial adhesion (the first stage of biofilm formation) but have also antiproliferative effects on mammalian cells [88]. Polymyxin B has antibacterial activity against Gram-negative bacteria by binding selectively to lipopolysaccharide (LPS) [91]. Daptomycin shows high antibacterial activity in the presence of $\mathrm{Ca}^{2+}$; the mode of action is still unknown but it induces permeabilization and depolarization of the bacterial cell membrane [92]. Iturin [93] and fengycin [94] strongly inhibit growth of filamentous fungi; the mode of action of fengycin is dose dependent: at low dose it induces apoptosis and at high dose necrosis [95].

Finally, there is the question whether the anucleated mammalian erythrocytes possess functional immune receptors that are responsive to microbe-associated molecular patterns (MAMPs). The nucleated erythrocytes of fish and chicken express specific PRRs (pathogen recognition receptors) including members of the toll-like receptors (TLRs) and peptidoglycan recognition protein (PGRP) receptors and are also responsive to corresponding stimuli $[96,97]$. Therefore, an active role in pathogen recognition has been considered. However, mammalian erythrocytes lack DNA, cannot synthesize RNA, and in addition they also lack organelles such as mitochondria or Golgi apparatus and gain their energy essentially from glycolysis. It is therefore unlikely that they are responsive to immune stimulation. Nevertheless, they represent excellent model cells to study the impact of compounds on eryptosis and membrane damage.

\section{Conclusion}

If we compare the various activities of the Lpp (Pam1-3) in immune stimulation and induction of eryptosis one can observe at least two fundamental differences. Immune stimulation occurs already at very low concentrations $(0.5 \mu \mathrm{g} / \mathrm{m})$, a concentration where we see no signs for eryptosis. The highest immune stimulation was observed with Pam2, which is sensed by the TLR2/TLR6 heterodimer [9]. On the other hand the highest activity in eryptosis was mediated by Pam3, the higher the degree of acylation the stronger the eryptosis. Finally, the concentration of Pam1-3 to induce eryptosis is roughly ten times higher than that required for immune stimulation. The results also show that Pam1-3 as representative of bacterial Lpp not only contribute to immune stimulation but damage at higher concentration also the host cells, thus aggravating an infection.

\section{Abbreviations}

PS, (phosphatidylserine); Lpp, (lipopeptides(s)); Pam1, ((Pam-Dhc-CSK4) synthetic monopalmitoylated lipopeptide); Pam2, ( $\left(\mathrm{Pam}_{2} \mathrm{CSK}_{4}\right)$ synthetic dipalmitoylated lipopeptide that mimicks the acylated amino terminus of bacterial lipoproteins); $\mathrm{Pam} 3,\left(\left(\mathrm{Pam}_{3} \mathrm{CSK}_{4}\right)\right.$ synthetic tripalmitoylated lipopeptide); Ros, (Reactive oxygen species); TLR, (toll-like receptor). 


\section{Cellular Physiology Cell Physiol Biochem 2017;41:296-309 \begin{tabular}{l|l} 
and Biochemistry Publishedontne-January 30, 2017 & $\begin{array}{l}\text { (c) } 2017 \text { The Author(s). Published by S. Karger AG, Basel } \\
\text { www.karger.com/cpb }\end{array}$
\end{tabular}}

Al Mamun Bhuyan et al.: Lipopeptide-Induced Eryptosis

\section{Acknowledgements}

The authors acknowledge Tanja Loch in helping to prepare the manuscript. The Deutsche Forschungsgemeinschaft TR-SFB34 supported the study and Open Access Publishing Fund of Tuebingen University.

\section{Disclosure Statement}

All authors declare that there are no conflicts of interest.

\section{References}

1 Nguyen MT, Götz F: Lipoproteins of Gram-Positive Bacteria: Key Players in the Immune Response and Virulence. Microbiol Mol Biol Rev 2016;80:891-903.

2 Shahmirzadi SV, Nguyen MT, Götz F: Evaluation of Staphylococcus aureus Lipoproteins: Role in Nutritional Acquisition and Pathogenicity. Front Microbiol 2016;7:1404.

3 Takeda K, Takeuchi O, Akira S: Recognition of lipopeptides by Toll-like receptors. J Endotoxin Res 2002;8:459-463.

4 Aliprantis AO, Yang RB, Mark MR, Suggett S, Devaux B, Radolf JD, Klimpel GR, Godowski P, Zychlinsky A: Cell activation and apoptosis by bacterial lipoproteins through toll-like receptor-2. Science 1999;285:736-739.

5 Deres K, Schild H, Wiesmuller KH, Jung G, Rammensee HG: In vivo priming of virus-specific cytotoxic T lymphocytes with synthetic lipopeptide vaccine. Nature 1989;342:561-564.

-6 Spohn R, Buwitt-Beckmann U, Brock R, Jung G, Ulmer AJ, Wiesmüller KH: Synthetic lipopeptide adjuvants and Toll-like receptor 2--structure-activity relationships. Vaccine 2004;22:2494-2499.

7 Rawadi G, Garcia J, Lemercier B, Roman-Roman S: Signal transduction pathways involved in the activation of NF-kappa B, AP-1, and c-fos by Mycoplasma fermentans membrane lipoproteins in macrophages. J Immunol 1999;162:2193-2203.

8 Bulut Y, Faure E, Thomas L, Equils O, Arditi M: Cooperation of Toll-like receptor 2 and 6 for cellular activation by soluble tuberculosis factor and Borrelia burgdorferi outer surface protein A lipoprotein: role of Toll-interacting protein and IL-1 receptor signaling molecules in Toll-like receptor 2 signaling. J Immunol 2001;167:987-994.

-9 Takeuchi O, Kawai T, Muhlradt PF, Morr M, Radolf JD, Zychlinsky A, Takeda K, Akira S: Discrimination of bacterial lipoproteins by Toll-like receptor 6. Int Immunol 2001;13:933-940.

10 Takeuchi O, Sato S, Horiuchi T, Hoshino K, Takeda K, Dong Z, Modlin RL, Akira S: Cutting edge: role of Tolllike receptor 1 in mediating immune response to microbial lipoproteins. J Immunol 2002;169:10-14.

11 Takeda K, Akira S: TLR signaling pathways. Semin Immunol 2004;16:3-9.

12 Kempe DS, Akel A, Lang PA, Hermle T, Biswas R, Muresanu J, Friedrich B, Dreischer P, Wolz C, Schumacher U, Peschel A, Götz F, Döring G, Wieder T, Gulbins E, Lang F: Suicidal erythrocyte death in sepsis. J Mol Med (Berl) 2007;85:273-281.

13 Alzoubi K, Calabro S, Bissinger R, Abed M, Faggio C, Lang F: Stimulation of suicidal erythrocyte death by artesunate. Cell Physiol Biochem 2014;34:2232-2244.

14 Abed M, Towhid ST, Mia S, Pakladok T, Alesutan I, Borst O, Gawaz M, Gulbins E, Lang F: Sphingomyelinaseinduced adhesion of eryptotic erythrocytes to endothelial cells. Am J Physiol Cell Physiol 2012;303:C991999.

15 Bissinger R, Lang E, Ghashghaeinia M, Singh Y, Zelenak C, Fehrenbacher B, Honisch S, Chen H, Fakhri H, Umbach AT, Liu G, Rexhepaj R, Liu G, Schaller M, Mack AF, Lupescu A, Birnbaumer L, Lang F, Qadri SM: Blunted apoptosis of erythrocytes in mice deficient in the heterotrimeric G-protein subunit Galphai2. Sci Rep 2016;6:30925.

16 Lau IP, Chen H, Wang J, Ong HC, Leung KC, Ho HP, Kong SK: In vitro effect of CTAB- and PEG-coated gold nanorods on the induction of eryptosis/erythroptosis in human erythrocytes. Nanotoxicology 2012;6:847856. 


\section{Cellular Physiology Cell Physiol Biochem 2017;41:296-309 \begin{tabular}{ll|l} 
DOI: 10.1159/000456147 & Ond Biochemistry Publisned online: January 30, 2017 & $\begin{array}{l}\text { 2 2017 The Author(s). Published by S. Karger AG, Basel } \\
\text { www.karger.com/cpb }\end{array}$
\end{tabular}}

Al Mamun Bhuyan et al.: Lipopeptide-Induced Eryptosis

17 Maellaro E, Leoncini S, Moretti D, Del Bello B, Tanganelli I, De Felice C, Ciccoli L: Erythrocyte caspase-3 activation and oxidative imbalance in erythrocytes and in plasma of type 2 diabetic patients. Acta Diabetol 2013;50:489-495.

18 Lang E, Bissinger R, Fajol A, Salker MS, Singh Y, Zelenak C, Ghashghaeinia M, Gu S, Jilani K, Lupescu A, Reyskens KM, Ackermann TF, Foller M, Schleicher E, Sheffield WP, Arthur JS, Lang F, Qadri SM: Accelerated apoptotic death and in vivo turnover of erythrocytes in mice lacking functional mitogen- and stressactivated kinase MSK1/2. Sci Rep 2015;5:17316.

19 Bissinger R, Kempe-Teufel DS, Honisch S, Qadri SM, Randrianarisoa E, Haring HU, Henes J, Lang F: Stimulated Suicidal Erythrocyte Death in Arteritis. Cell Physiol Biochem 2016;39:1068-1077.

-20 Egler J, Lang F: Licochalcone A Induced Suicidal Death of Human Erythrocytes. Cell Physiol Biochem 2015;37:2060-2070.

21 Lang E, Pozdeev VI, Gatidis S, Qadri SM, Haussinger D, Kubitz R, Herebian D, Mayatepek E, Lang F, Lang KS, Lang PA: Bile Acid-Induced Suicidal Erythrocyte Death. Cell Physiol Biochem 2016;38:1500-1509.

-22 Lang E, Qadri SM, Lang F: Killing me softly - suicidal erythrocyte death. Int J Biochem Cell Biol 2012;44:1236-1243.

23 Lupescu A, Bissinger R, Goebel T, Salker MS, Alzoubi K, Liu G, Chirigiu L, Mack AF, Qadri SM, Lang F: Enhanced suicidal erythrocyte death contributing to anemia in the elderly. Cell Physiol Biochem 2015;36:773-783.

24 Qadri SM, Mahmud H, Lang E, Gu S, Bobbala D, Zelenak C, Jilani K, Siegfried A, Foller M, Lang F: Enhanced suicidal erythrocyte death in mice carrying a loss-of-function mutation of the adenomatous polyposis coli gene. J Cell Mol Med 2012;16:1085-1093.

25 Ran Q Xiang Y, Liu Y, Xiang L, Li F, Deng X, Xiao Y, Chen L, Chen L, Li Z: Eryptosis Indices as a Novel Predictive Parameter for Biocompatibility of Fe304 Magnetic Nanoparticles on Erythrocytes. Sci Rep 2015;5:16209.

-26 Bissinger R, Schumacher C, Qadri SM, Honisch S, Malik A, Gotz F, Kopp HG, Lang F: Enhanced eryptosis contributes to anemia in lung cancer patients. Oncotarget 2016;7:14002-14014.

-27 Lang E, Gatidis S, Freise NF, Bock H, Kubitz R, Lauermann C, Orth HM, Klindt C, Schuier M, Keitel V, Reich M, Liu G, Schmidt S, Xu HC, Qadri SM, Herebian D, Pandyra AA, Mayatepek E, Gulbins E, Lang F, Haussinger D, Lang KS, Foller M, Lang PA: Conjugated bilirubin triggers anemia by inducing erythrocyte death. Hepatology 2015;61:275-284.

-28 Lang E, Pozdeev VI, Xu HC, Shinde PV, Behnke K, Hamdam JM, Lehnert E, Scharf RE, Lang F, Haussinger D, Lang KS, Lang PA: Storage of Erythrocytes Induces Suicidal Erythrocyte Death. Cell Physiol Biochem 2016;39:668-676.

29 Bissinger R, Barking S, Alzoubi K, Liu G, Liu G, Lang F: Stimulation of Suicidal Erythrocyte Death by the Antimalarial Drug Mefloquine. Cell Physiol Biochem 2015;36:1395-1405.

-30 Bouguerra G, Aljanadi O, Bissinger R, Abbes S, Lang F: Embelin-Induced Phosphatidylserine Translocation in the Erythrocyte Cell Membrane. Cell Physiol Biochem 2015;37:1629-1640.

-31 Bouguerra G, Bissinger R, Abbes S, Lang F: Stimulation of Eryptosis by Narasin. Cell Physiol Biochem 2015;37:1807-1816.

32 Bissinger R, Bouguerra G, Stockinger K, Abbes S, Lang F: Triggering of Suicidal Erythrocyte Death by Topotecan. Cell Physiol Biochem 2015;37:1607-1618.

33 Briglia M, Fazio A, Faggio C, Laufer S, Alzoubi K, Lang F: Triggering of Suicidal Erythrocyte Death by Ruxolitinib. Cell Physiol Biochem 2015;37:768-778.

-34 Briglia M, Calabro S, Signoretto E, Alzoubi K, Laufer S, Faggio C, Lang F: Fucoxanthin Induced Suicidal Death of Human Erythrocytes. Cell Physiol Biochem 2015;37:2464-2475.

-35 Alzoubi K, Egler J, Abed M, Lang F: Enhanced eryptosis following auranofin exposure. Cell Physiol Biochem 2015;37:1018-1028.

-36 Fazio A, Briglia M, Faggio C, Alzoubi K, Lang F: Stimulation of Suicidal Erythrocyte Death by Garcinol. Cell Physiol Biochem 2015;37:805-815.

37 Briglia M, Fazio A, Faggio C, Lang F: Triggering of Suicidal Erythrocyte Death by Zosuquidar. Cell Physiol Biochem 2015;37:2355-2365.

-38 Officioso A, Alzoubi K, Manna C, Lang F: Clofazimine Induced Suicidal Death of Human Erythrocytes. Cell Physiol Biochem 2015;37:331-341. 


\section{Cellular Physiology Cell Physiol Biochem 2017;41:296-309

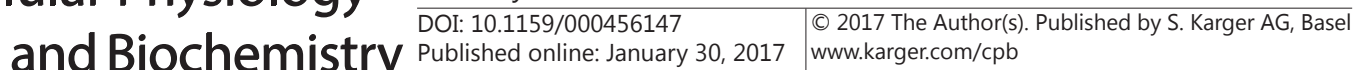

Al Mamun Bhuyan et al.: Lipopeptide-Induced Eryptosis

-39 Peter T, Bissinger R, Enkel S, Alzoubi K, Oswald G, Lang F: Programmed erythrocyte death following in vitro Treosulfan treatment. Cell Physiol Biochem 2015;35:1372-1380.

-40 Stockinger K, Bissinger R, Bouguerra G, Abbes S, Lang F: Enhanced Eryptosis Following Exposure to Carnosic Acid. Cell Physiol Biochem 2015;37:1779-1791.

-41 Waibel S, Bissinger R, Bouguerra G, Abbes S, Lang F: Saquinavir Induced Suicidal Death of Human Erythrocytes. Cell Physiol Biochem 2015;37:1973-1982.

42 Zierle J, Bissinger R, Egler J, Lang F: Lapatinib Induced Suicidal Death of Human Erythrocytes. Cell Physiol Biochem 2015;37:2275-2287.

43 Macczak A, Cyrkler M, Bukowska B, Michalowicz J: Eryptosis-inducing activity of bisphenol A and its analogs in human red blood cells (in vitro study). J Hazard Mater 2016;307:328-335.

44 Officioso A, Alzoubi K, Lang F, Manna C: Hydroxytyrosol inhibits phosphatidylserine exposure and suicidal death induced by mercury in human erythrocytes: Possible involvement of the glutathione pathway. Food Chem Toxicol 2016;89:47-53.

45 Qadri SM, Donkor DA, Bhakta V, Eltringham-Smith LJ, Dwivedi DJ, Moore JC, Pepler L, Ivetic N, Nazi I, FoxRobichaud AE, Liaw PC, Sheffield WP: Phosphatidylserine externalization and procoagulant activation of erythrocytes induced by Pseudomonas aeruginosa virulence factor pyocyanin. J Cell Mol Med 2016;20:710720.

46 Zierle J, Bissinger R, Bouguerra G, Abbes S, Lang F: Triggering of Suicidal Erythrocyte Death by Regorafenib. Cell Physiol Biochem 2016;38:160-172.

-47 Al Mamun Bhuyan A, Bissinger R, Stockinger K, Lang F: Stimulation of Suicidal Erythrocyte Death by Tafenoquine. Cell Physiol Biochem 2016;39:2464-2476.

-48 Al Mamun Bhuyan A, Signoretto E, Bissinger R, Lang F: Enhanced Eryptosis Following Exposure to Dolutegravir. Cell Physiol Biochem 2016;39:639-650.

-49 Al Mamun Bhuyan A, Signoretto E, Lang F: Triggering of Suicidal Erythrocyte Death by Psammaplin A. Cell Physiol Biochem 2016;39:908-918.

50 Almasry M, Jemaa M, Mischitelli M, Faggio C, Lang F: Stimulation of Suicidal Erythrocyte Death by Phosphatase Inhibitor Calyculin A. Cell Physiol Biochem 2016;40:163-171.

51 Bissinger R, Bhuyan AA, Signoretto E, Lang F: Stimulating Effect of Elvitegravir on Suicidal Erythrocyte Death. Cell Physiol Biochem 2016;38:1111-1120.

52 Egler J, Zierle J, Lang F: Stimulating Effect of Manumycin A on Suicidal Erythrocyte Death. Cell Physiol Biochem 2016;38:1147-1156.

53 Jemaa M, Mischitelli M, Fezai M, Almasry M, Faggio C, Lang F: Stimulation of Suicidal Erythrocyte Death by the CDC25 Inhibitor NSC-95397. Cell Physiol Biochem 2016;40:597-607.

54 Mischitelli M, Jemaa M, Almasry M, Faggio C, Lang F: Stimulation of Erythrocyte Cell Membrane Scrambling by Quinine. Cell Physiol Biochem 2016;40:657-667.

55 Mischitelli M, Jemaa M, Almasry M, Faggio C, Lang F: Stimulation of Suicidal Erythrocyte Death by Rottlerin. Cell Physiol Biochem 2016;40:558-566.

56 Mischitelli M, Jemaa M, Almasry M, Faggio C, Lang F: Triggering of Erythrocyte Cell Membrane Scrambling by Emodin. Cell Physiol Biochem 2016;40:91-103.

\$57 Mischitelli M, Jemaa M, Almasry M, Faggio C, Lang F: Triggering of Suicidal Erythrocyte Death by Fascaplysin. Cell Physiol Biochem 2016;39:1638-1647.

58 Mischitelli M, Jemaa M, Almasry M, Faggio C, Lang F: Ca2+ Entry, Oxidative Stress, Ceramide and Suicidal Erythrocyte Death Following Diosgenin Treatment. Cell Physiol Biochem 2016;39:1626-1637.

-59 Peter T, Bissinger R, Lang F: Stimulation of Eryptosis by Caspofungin. Cell Physiol Biochem 2016;39:939949.

60 Peter T, Bissinger R, Liu G, Lang F: Anidulafungin-Induced Suicidal Erythrocyte Death. Cell Physiol Biochem 2016;38:2272-2284.

61 Peter T, Bissinger R, Signoretto E, Mack AF, Lang F: Micafungin-Induced Suicidal Erythrocyte Death. Cell Physiol Biochem 2016;39:584-595.

62 Pretorius E, du Plooy JN, Bester J: A Comprehensive Review on Eryptosis. Cell Physiol Biochem 2016;39:1977-2000.

63 Shan F, Yang R, Ji T, Jiao F: Vitamin C Inhibits Aggravated Eryptosis by Hydrogen Peroxide in Glucose-6Phosphated Dehydrogenase Deficiency. Cell Physiol Biochem 2016;39:1453-1462. 


\section{Cellular Physiology Cell Physiol Biochem 2017;41:296-309

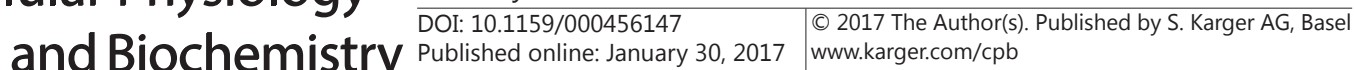

Al Mamun Bhuyan et al.: Lipopeptide-Induced Eryptosis

64 Signoretto E, Bissinger R, Castagna M, Lang F: Stimulation of Eryptosis by Combretastatin A4 Phosphate Disodium (CA4P). Cell Physiol Biochem 2016;38:969-981.

-65 Signoretto E, Castagna M, Al Mamun Bhuyan A, Lang F: Stimulating Effect of Terfenadine on Erythrocyte Cell Membrane Scrambling. Cell Physiol Biochem 2016;38:1425-1434.

-66 Signoretto E, Castagna M, Lang F: Stimulation of Eryptosis, the Suicidal Erythrocyte Death by Piceatannol. Cell Physiol Biochem 2016;38:2300-2310.

67 Signoretto E, Honisch S, Briglia M, Faggio C, Castagna M, Lang F: Nocodazole Induced Suicidal Death of Human Erythrocytes. Cell Physiol Biochem 2016;38:379-392.

-68 Signoretto E, Laufer SA, Lang F: Stimulating Effect of Sclareol on Suicidal Death of Human Erythrocytes. Cell Physiol Biochem 2016;39:554-564.

69 Signoretto E, Zierle J, Bissinger R, Castagna M, Bossi E, Lang F: Triggering of Suicidal Erythrocyte Death by Pazopanib. Cell Physiol Biochem 2016;38:926-938.

70 Wesseling MC, Wagner-Britz L, Huppert H, Hanf B, Hertz L, Nguyen DB, Bernhardt I: Phosphatidylserine Exposure in Human Red Blood Cells Depending on Cell Age. Cell Physiol Biochem 2016;38:1376-1390.

71 Zierle J, Bissinger R, Lang F: Inhibition by Teriflunomide of Erythrocyte Cell Membrane Scrambling Following Energy Depletion, Oxidative Stress and Ionomycin. Cell Physiol Biochem 2016;39:1877-1890.

72 Wang K, Mahmud H, Foller M, Biswas R, Lang KS, Bohn E, Götz F, Lang F: Lipopeptides in the triggering of erythrocyte cell membrane scrambling. Cell Physiol Biochem 2008;22:381-386.

73 Srinivas SP, Bonanno JA, Lariviere E, Jans D, Van Driessche W: Measurement of rapid changes in cell volume by forward light scattering. Pflugers Arch 2003;447:97-108.

-74 Nguyen MT, Hanzelmann D, Hartner T, Peschel A, Götz F: Skin-Specific Unsaturated Fatty Acids Boost the Staphylococcus aureus Innate Immune Response. Infect Immun 2015;84:205-215.

-75 Lang PA, Kaiser S, Myssina S, Wieder T, Lang F, Huber SM: Role of Ca2+-activated K+ channels in human erythrocyte apoptosis. Am J Physiol Cell Physiol 2003;285:C1553-1560.

-76 Browning JA, Ellory JC, Gibson JS: Pathophysiology of red cell volume. Contrib Nephrol 2006;152:241-268.

-77 Suzuki J, Fujii T, Imao T, Ishihara K, Kuba H, Nagata S: Calcium-dependent phospholipid scramblase activity of TMEM16 protein family members. J Biol Chem 2013;288:13305-13316.

-78 Kurokawa K, Lee H, Roh KB, Asanuma M, Kim YS, Nakyama H, Shiratsuchi A, Choi Y, Takeuchi O, Kang HJ, Dohmae N, Nakanishi Y, Akira S, Sekimizu K, Lee BL: The triacylated ATP binding cluster transporter substrate-binding lipoprotein of Staphylococcus aureus functions as a native ligand for the toll-like receptor 2. J Biol Chem 2009;

79 Skabytska Y, Wolbing F, Gunther C, Koberle M, Kaesler S, Chen KM, Guenova E, Demircioglu D, Kempf WE, Volz T, Rammensee HG, Schaller M, Röcken M, Götz F, Biedermann T: Cutaneous innate immune sensing of Toll-like receptor 2-6 ligands suppresses $\mathrm{T}$ cell immunity by inducing myeloid-derived suppressor cells. Immunity 2014;41:762-775.

-80 Kuypers FA: Phospholipid asymmetry in health and disease. Curr Opin Hematol 1998;5:122-131.

-81 Zwaal RF, Schroit AJ: Pathophysiologic implications of membrane phospholipid asymmetry in blood cells. Blood 1997;89:1121-1132.

-82 Schlegel RA, Prendergast TW, Williamson P: Membrane phospholipid asymmetry as a factor in erythrocyteendothelial cell interactions. J Cell Physiol 1985;123:215-218.

83 Boas FE, Forman L, Beutler E: Phosphatidylserine exposure and red cell viability in red cell aging and in hemolytic anemia. Proc Natl Acad Sci U S A 1998;95:3077-3081.

84 Nagata S: Apoptosis by death factor. Cell 1997;88:355-365.

-85 Asano K, Miwa M, Miwa K, Hanayama R, Nagase H, Nagata S, Tanaka M: Masking of phosphatidylserine inhibits apoptotic cell engulfment and induces autoantibody production in mice. J Exp Med 2004;200:459467.

-86 Calderon-Salinas JV, Munoz-Reyes EG, Guerrero-Romero JF, Rodriguez-Moran M, Bracho-Riquelme RL, Carrera-Gracia MA, Quintanar-Escorza MA: Eryptosis and oxidative damage in type 2 diabetic mellitus patients with chronic kidney disease. Mol Cell Biochem 2011;357:171-179.

-87 Raftos JE, Whillier S, Chapman BE, Kuchel PW: Kinetics of uptake and deacetylation of N-acetylcysteine by human erythrocytes. Int J Biochem Cell Biol 2007;39:1698-1706.

-88 Janek T, Rodrigues LR, Gudina EJ, Czyznikowska Z: Structure and mode of action of cyclic lipopeptide pseudofactin II with divalent metal ions. Colloids Surf B Biointerfaces 2016;146:498-506. 


\section{Cellular Physiology Cell Physiol Biochem 2017;41:296-309

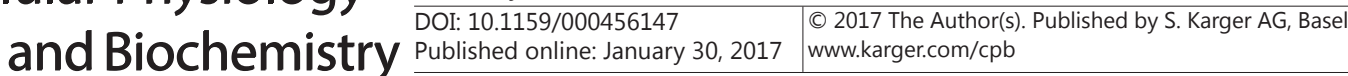

Al Mamun Bhuyan et al.: Lipopeptide-Induced Eryptosis

89 Grau A, Gomez Fernandez JC, Peypoux F, Ortiz A: A study on the interactions of surfactin with phospholipid vesicles. Biochim Biophys Acta 1999;1418:307-319.

90 Buchoux S, Lai-Kee-Him J, Garnier M, Tsan P, Besson F, Brisson A, Dufourc EJ: Surfactin-triggered small vesicle formation of negatively charged membranes: a novel membrane-lysis mechanism. Biophys J 2008;95:3840-3849.

91 Velkov T, Thompson PE, Nation RL, Li J: Structure--activity relationships of polymyxin antibiotics. J Med Chem 2010;53:1898-1916.

92 Taylor SD, Palmer M: The action mechanism of daptomycin. Bioorg Med Chem 2016;24:6253-6268.

\$3 Raaijmakers JM, De Bruijn I, Nybroe 0, Ongena M: Natural functions of lipopeptides from Bacillus and Pseudomonas: more than surfactants and antibiotics. FEMS Microbiol Rev 2010;34:1037-1062.

94 Wu CY, Chen CL, Lee YH, Cheng YC, Wu YC, Shu HY, Götz F, Liu ST: Nonribosomal Synthesis of Fengycin on an Enzyme Complex Formed by Fengycin Synthetases. J Biol Chem 2007;282:5608-5616.

$\$ 95$ Tang Q, Bie X, Lu Z, Lv F, Tao Y, Qu X: Effects of fengycin from Bacillus subtilis fmbJ on apoptosis and necrosis in Rhizopus stolonifer. J Microbiol 2014;52:675-680.

-96 Rodriguez MF, Wiens GD, Purcell MK, Palti Y: Characterization of Toll-like receptor 3 gene in rainbow trout (Oncorhynchus mykiss). Immunogenetics 2005;57:510-519.

-97 Morera D, Roher N, Ribas L, Balasch JC, Donate C, Callol A, Boltana S, Roberts S, Goetz G, Goetz FW, MacKenzie SA: RNA-Seq reveals an integrated immune response in nucleated erythrocytes. PLoS One 2011;6:e26998. 